\title{
DON QUIJOTE Y LOS LITERATOS ÁRABES
}

\author{
Clara $M^{a}$ Thomas de Antonio \\ Universidad de Sevilla
}

\begin{abstract}
This is a brief exposition about the way in which the Modern Arabic Literature has received the principal characters of Cervantes's immortal Don Quijote de la Mancha. The political and social conditions of the Arab World had a great influence on their perception of the symbolic signification of those universal personages, specially after the Arab defeat in Palestina (June 1967).
\end{abstract}

El tema andalusí ha sido especialmente abordado por los literatos árabes, como pone de relieve Martínez Montávez en Al-Andalus, España, en la literatura árabe contemporánea $(1992)^{1}$, donde el autor también aclara que el tema estrictamente hispánico ha sido tratado con menos emotividad o cierto distanciamiento, pues tal vez se siente más ajeno y "venido de fuera", mientras que lo andalusí se siente como propio, aunque se haya perdido, y por tanto "surge de dentro"; y un ejemplo de esta diferencia lo constituye el tratamiento que se da a la figura de Don Quijote, que por su dimensión mítica y universal conviene a las circunstancias del mundo árabe contemporáneo y en especial al último tiempo de gran derrota (Martínez Montávez, 1992: 260-261).

Por otro lado, $\mathrm{M}^{\mathrm{a}} \mathrm{J}$. Viguera (1999: 1), que ha estudiado este tema cervantino en varias ocasiones, señala la capacidad de la literatura árabe para arabizar arquetipos universales, como es el caso del personaje que Miguel de Cervantes (1546-1616) inmortalizara en Don Quijote de la Mancha (1605), hacia cuya figura y valores muestran gran admiración.

La traducción al árabe de Don Quijote de la Mancha fue algo tardía en relación a otras obras de la literatura universal. Muestra de ello es el testimonio de Muhammad Husni ${ }^{c}$ Umar, nombrado embajador de Egipto en España en 1950, cuando quiso documentarse sobre nuestro país; dice en Memorias de mi misión en España (Mudakkirati 'an ba tati fi Isbaniya, 1956):

Poco antes de mi viaje a España, recorrí las más famosas librerías de El Cairo y Alejandría, sin hallar ningún libro o revista hispana, ni traducción tampoco de una sola obra española, todo lo más, una versión resumida, en inglés, de Don Quijote de la Mancha (Viguera, 1975: 146).

Pero pronto empezó a paliarse esa carencia, pues una de las primeras obras españolas en ser traducidas al árabe fue precisamente El ingenioso hidalgo Don Quijote de la Mancha (Al-sayyid al- ${ }^{a}$ abqari Dun Kijutih di La Manša, 1957), versión sólo de la primera parte, realizada por el profesor egipcio ${ }^{\mathrm{C}} \mathrm{Abd}$ al- ${ }^{\mathrm{c}} \mathrm{Aziz}$ al-Ahwani y prologada por el hispanista Husayn Mu'nis. Al año siguiente aparecerán en Beirut El caballero loco (Al-faris al-

\footnotetext{
${ }^{1}$ En esta obra crucial y pionera sobre el tema, Martínez Montávez va desgranando a lo largo de sus casi trescientas páginas muchas de las incursiones que los autores árabes contemporáneos han hecho en él.
} 
maynun, 1958) y Vuelta a la razón ('Awda ilà l-sawab), breves adaptaciones realizadas por Misal Abu Sacb. Y, aunque hacia 1960 aparece en El Cairo una adaptación infantil de Don Quijote (Dun Kišut) -lo que da idea de la difusión del personaje-, hasta 1965 no se publica la versión íntegra en dos volúmenes, Don Quijote (Dun Kijutih), del profesor egipcio 'Abd al-Rahman Badawi, con un importante estudio introductorio sobre el autor, la novela y las circunstancias históricas y sociales en las que surgió, e ilustraciones de Gustavo Doré; esta obra se reeditará en 1998 en Damasco-Abu Dabi (Viguera, 1999: 3, 45) ${ }^{2}$.

Según Martínez Montávez (1992: 188), Don Quijote es uno de los personajes de la literatura universal que mayor interés despiertan entre los intelectuales egipcios, que ofrecen las muestras más destacables sobre el tema, y que, salvo cuando son hispanistas, lo hacen a través de lenguas intermedias, como el inglés o el francés ${ }^{3}$.

La literatura árabe moderna ha abordado en todos sus géneros el personaje de Cervantes de acuerdo a las circunstancias históricas y socio-culturales en que el literato estuviera inmerso. Pero, a grandes rasgos, se pueden diferenciar dos grandes etapas, separadas por una fecha clave en el devenir del mundo árabe: junio de 1967, en que se produjo la derrota árabe en Palestina, cuyas consecuencias siguen marcando el panorama actual de Oriente Medio.

$$
* * *
$$

Antes de junio de 1967 los autores egipcios son los que más se van a ocupar de Cervantes y Don Quijote. Viguera (1975: 145; 1999: 5), que en 1975 estudió cuatro ensayos egipcios, constata que éstos se han difundido mucho, y que la mayoría de sus autores conocen el tema por medio de fuentes no españolas, lo que considera una muestra de la apertura de la cultura árabe a lo universal en la etapa de su renacer (nahda), evidenciada en la intensa labor traductora que se produce especialmente en Egipto en esa época.

En 1944, Muhammad Mandur (1907-1965) -que estudió nueve años en la Sorbona, doctorándose en literatura- incluye a "Don Quijote" (Dun Kišut) entre sus Arquetipos humanos ${ }^{4}$, situándolo entre figuras como Fausto, Hamlet, Beatriz o Ulises. Este ensayo aporta datos sobre el autor, la obra y el personaje para el lector árabe; un resumen de los principales episodios de la novela; y un análisis del autor y su personaje como dos figuras

\footnotetext{
${ }^{2}$ Entre los estudios sobre la obra cervantina destacan un primer ensayo breve sobre el Quijote de Muhammad Mandur en 1944; o Cervantes, principe de la literatura española (Sirfantis, amir al-adab al-isbani, 1947), estudio publicado en Tetuán por Nayib Abu Malham y Musà c Abbud, profesores de origen libanés que desempeñaban su labor en el Protectorado español de Marruecos (Martínez Montávez, 1992: 188-189; Viguera, 1999: 3). Otros breves ensayos de primera época, como luego se verá, los realizan los egipcios al- ${ }^{c} A$ lim (1956), Mu'nis (1957) y al-Naqqaš (1958). En 1968 se edita en Madrid Don Quijote en el siglo XX: Selección de ensayos españoles (Dun Kijuti fi l-qarn al-išrin: Mujtarat min maqalat isbaniya, 1968), obra en la que Mahmud Subh y Julio Cortés traducen al árabe artículos de Ortega Unamuno, Maeztu y Azorín; también se publicarán otras traducciones al árabe de ensayos españoles sobre el personaje, como los de Unamuno (1987) o Buero Vallejo (1979). A ello hay que añadir numerosos trabajos árabes sobre el tema, como los de Biyar Ginun (1979), If Yamiyak (1987), Gabriyal Wahba (1989), Gali Šukri (1991) o Muhammad Ahmad al-Šinwani (1995).

${ }^{3}$ La trascripción al árabe del término "Don Quijote" (Dun Kišut o Dun Kijuti-Kijutih) puede dar una pista sobre las fuentes empleadas.

${ }^{4}$ Namadiy bašariya (1944), polémica obrita, de fuerte influencia francesa, reeditada en numerosas ocasiones. Traducción completa de este ensayo en Viguera (1975: 148-153).
} 
en crisis, conectando las fracasadas biografías de Cervantes y su Quijote como fruto del conflicto universal entre contrarios -realismo/idealismo, justicia/opresión, locura/razón, juventud/vejez- que se produce en el interior de cada ser humano, no tanto en la sociedad (Viguera, 1999: 5-7).

Mandur hace de su Quijote el símbolo de los sueños de juventud, aventados por las dificultades de la vida. Comienza su ensayo con la leyenda del gigante griego Anteo, que sólo pudo ser vencido por Hércules cuando éste logró separarle los pies de la madre tierra que le daba su poder. De esta leyenda parte su breve repaso de la difícil vida de Cervantes, marcada, según el autor, por el sentido de este mito:

Tuvo, desde la infancia, cumplida fantasía, lo mismo que la tuvo Don Quijote (...) Quiso el Hado que Cervantes fracasara en todas las etapas de su vida (...). Tuvo razón Cervantes si condenó la vida y tornó a los sueños de sus años mozos para tener al menos un pie seguro en tierra (...). Sus dolores se trocaron en burla de sus sueños que habían propiciado sus fracasos; pero era una ironía transida de la dulzura de aquellas esperanzas (...). Por mucha ilusión que rechacemos (...), la añoramos y la amamos sin remedio (Viguera, 1975: 149,150).

Para Mandur, Cervantes quiso triunfar con la espada y la pluma, pero su nombre sólo se hizo eterno al imbuir a su Quijote de sus propias aventuras fantásticas. A continuación ofrece las distintas interpretaciones que se hacen de este personaje:

Su personalidad es tan rica que sirve de símbolo múltiple. Para unos es un loco tan sólo, que se cree campeón de los males del mundo e intenta deshacerlos, recibiendo sus golpes o llevándolos a lugar indebido. Otros dicen que no es sino un pertinaz idealista que continuamente choca son la amarga realidad de la vida, y el fracaso acaba rindiéndole a la muerte. Hay algunos que saben entenderle y a su través perciben lo que es la juventud, intuyen el impulso de la vida; no es necesario el éxito si luchamos por un alto ideal en el que creemos y al que damos la vida, pues luchar es en sí un fin nobilísimo. ¿Y cuándo la nobleza precisó resultados? (Viguera, 1975: 150-151).

Luego va comentando diversos pasajes de la novela de Cervantes, para constatar su estado de ánimo ante los diversos fracasos y sinsabores:

¡Qué impotente se hallaba frente a las injusticias debido a la corrupción del alma de los hombres! ¡Cuántas veces halló la más vil recompensa a sus desvelos! ¡Cómo el destino desbarató su esfuerzo! (Viguera, 1975: 152).

También intercala algunos diálogos entre Don Quijote -encarnación de la locura y el idealismo- y su escudero Sancho -encarnación de la realidad y la razón-, que se ha separado de aquél para gobernar su ínsula y retornar luego junto a su amo, para concluir diciendo:

Hete aquí a Sancho que abandona su fantástica vida para volver con Don Quijote. ¡Curioso, que la Razón insista en acompañar a la Locura de tal modo (Viguera, 1975: 152).

Y tras exponer el triste final de Don Quijote, que "murió tras darse cuenta de que la lucha por el bien de los hombres es luchar con molinos de viento" (Viguera, 1975: 153), y aludir a otros "locos" famosos, Mandur expone su propia opinión sobre el personaje:

Ese mundo tan bello que tuvieron esas almas extrañas quizás sea el mundo verdadero. El mundo que el hombre debería vivir si quisiera poner su corazón en un alto ideal.

Don Quijote murió en la obra de Cervantes, pero continúa vivo en las mentes de todos los que han venido al mundo y seguirán viniendo, como símbolo de lo que el alma joven lleva dentro: 
afán de bien y entrega de la vida en conseguirlo. Símbolo de lo que arrebata el entusiasmo, y que los ignorantes denominan locura. Murió, pero su vida sigue como lección eterna de nobleza altruista en pos de una alta empresa (Viguera, 1975: 153).

Tras el aldabonazo cronológico del temprano ensayo de Mandur, habrá que esperar más de una década para que aparezcan otros ensayos egipcios que ayuden a aclimatar la figura del Quijote a las letras árabes. Si en Mandur el conflicto universal simbolizado por el personaje radica principalmente en el individuo, en los ensayistas egipcios de la siguiente generación sus motivaciones y conclusiones trascienden lo social, y a su vez tienen una aplicación ideológica (Viguera, 1995: 10, 17, 18). Así, en 1956, Mahmud Amin al- ${ }^{\mathrm{A}}$ Alim (n.1922) -que también conoce al personaje a través de la cultura francesa- va a apuntar en "Don Quijote-Cervantes: el profundo símbolo humano" (Dun Kišut-Sirfantis:al-ramz alinsani al- $\left.{ }^{c} a m i q\right)^{5}$ que toda figura literaria tiene raíces individualistas, pero que sus motivaciones y conclusiones transcienden al conjunto de la vida social (Viguera, 1999: 7). El ensayo contiene datos informativos sobre Cervantes y su personaje, y datos sobre la historia de España del XVI-principios del XVII, así como una aplicación ideológica, al sugerir que la crisis es la inadecuación entre teoría y praxis, entre un mundo de realidad siempre cambiante y un mundo inventado que no sabe ni puede evolucionar, e incluso se niega a progresar (Viguera, 1999: 9). Desde el propio título al- ${ }^{\mathrm{C}} \mathrm{Alim}$ ofrece su visión del personaje. Rechazando interpretaciones simplistas, lo define así:

Don Quijote no es un demente o un alucinado que combata a molinos de viento o que aspire a imponer sus fantasías y ensueños a un mundo de tenaz realidad. Fue el último caballero de una larga edad de caballería, heroísmo y nobleza, con su contrapartida: vasallaje y servidumbre. Don Quijote fue el último adiós a toda una época de la historia (Viguera, 1975: 154).

Al- ${ }^{\mathrm{C}}$ Alim piensa que Don Quijote asume las propias paradojas de la España de su tiempo (1605), en la que el feudalismo caducaba y se iba a iniciar una etapa de capitalismo basado en la producción industrial y la expansión de sus influencias, pero sin haber cimentado aún las bases idóneas de esa producción industrial. España se preocupó más en dominar a otros pueblos, de los que se abastecía, que en la producción y la industria propias, agotando la potencia de sus hijos y los recursos de su tierra. Y, según él, esta transición se refleja en los personajes cervantinos:

Don Quijote es un viejo ingenioso, hidalgo pero pobre, héroe sin guerras; su armadura es el eco de los sueños y singulares heroísmos de la Edad Media (...). Era también un hombre bueno que luchaba en pro de la justicia, el amor y la paz entre los hombres (...). Sus ilusiones chocaron con el enrarecido suelo de la realidad, pero él no perdía el ánimo ni tornaba en derrota, sino que culpaba de traición a aquella realidad. En su marcha veía a gigantes malignos, tomaba impulso y, con singular bravura, les acometía con su lanza y con su desafío. De pronto se trocaban los gigantes temibles en molinos de viento; igual que el feudalismo se había transformado en época de industria y producción (...). El caballero regresa derrotado, simbolizando la derrota del feudalismo ante el nuevo régimen industrial (Viguera, 1975: 154, 156-157).

\footnotetext{
${ }^{5}$ En El hombre...una actitud (Al-insan...mawqif, 1956), reimpreso en 1972, lo que demuestra su difusión (Viguera, 1995: 14). Traducción completa de este ensayo en Viguera (1975: 154-159).
} 
A su vez, Sancho Panza representa para Al- ${ }^{\mathrm{c}}$ Alim al nuevo señor post-feudal y a la nueva realidad, pero sigue a su amo por afecto y porque comparte con él su afán por extender la justicia. Sancho y Don Quijote son un reflejo del propio Cervantes, hijo de su tiempo que participó en batallas, fue acosado por la Inquisición, echó en falta las experiencias heroicas de la sociedad feudal y fue engendrando el mensaje que transmitiría su Quijote: su amor a la justicia y su búsqueda de un mundo feliz. Y éstas son las ideas que lo han hecho inmortal. Uno de los fragmentos finales puede ser, según Martínez Montávez (1992: 189), el más representativo de la dimensión simbólica y universal de Don Quijote en estos ensayos:

Todos tenemos algún momento quijotesco. Todos tenemos algún momento en que se pone a prueba su heroísmo. Algunos de nosotros sólo ven gigantes encantados y gastan su potencia en luchar con molinos productivos. Otros hacen de su heroísmo una potencia nueva que mueve molinos, en vez de destruirlos. Algunos de nosotros llevan el pasado caduco encima de sus hombros, como armadura ferrada y pesadísima, que les atenaza e impide ver realmente a la gente y al futuro. Otros ven a la gente y al futuro con claridad y optimismo. Sólo cuando la bondad, la justicia, el amor y la paz nos llenan el corazón, encontramos entre nosotros a Don Quijote. Por eso es Don Quijote un profundo símbolo humano que, sobre su viejo caballo, salió de su rincón hispano y dio la vuelta al mundo y a los siglos, hasta nuestra época (Viguera, 1975: 158-159).

En 1957, el hispanista egipcio Husayn Mu'nis (1912-1995) -que fue director del Instituto Egipcio de Estudios Islámicos de Madrid y tradujo varias obras de literatura española al árabe- introdujo la versión árabe del Quijote de al-Ahwani (1957) con su ensayo "El alma andalusí en la obra de Cervantes" (Al-nafs al-andalusiya fi kitabat Tirfantis $)^{6}$. Desde su óptica de especialista en estudios andalusíes, ve a Cervantes como síntesis de todas las almas españolas, pues todos los tipos de españoles se hallan reflejados en su obra. Comienza señalando, con actitud crítica, el peso de la tradición islámica en España, que dejó huellas indelebles en su alma, representada por Don Quijote:

El Quijote, cuando sale a una empresa, pletórico de fuerza y entusiasmo, marcha haciendo voto de no cejar mientras que no la logre, pero, apenas alcanza una parte de ella, se desvía del resto. $\mathrm{Y}$ en esto se parece a los antepasados musulmanes de su tierra: salían contra los enemigos jurando no ceder hasta no destruirles por completo y, apenas alcanzaban algún éxito, permitían a sus tropas solazarse; este descanso les impedía continuar adelante, pues regresaban a festejar el triunfo (Viguera, 1975: 160).

También critica la complacencia en alabanzas del musulmán hispano:

Te vienen a las mientes unos antepasados suyos -el musulmán hispano- a los que el panegírico embriagaba y buscaban su incremento, aunque fuese una simple mentira; este elogio les apartaba de la acción importante y provechosa (Viguera, 1975: 161).

Así, la lectura del Quijote le hace pensar en al-Mu'tamid de Sevilla, trazando un paralelismo entre ambos personajes por su mismo entusiasmo en empresas para las que no ponen los medios adecuados, por su regreso fracasados que no mina su entusiasmo, por su final de hombres desprovistos de todo, por su derroche de energía e ilusiones, y por conformarse con irrealidades y delirios:

\footnotetext{
${ }^{6}$ Traducción completa de este ensayo en Viguera (1975: 159-168).
} 


\begin{abstract}
Al-Mu'tamid sueña con invadir Córdoba y canta en versos una victoria que va a ser la suya y en la que ningún otro le habrá sobrepasado; pero, apenas su ejército la ocupa, llega el enemigo, y ha de retirarse. Vuelven sus tropas deshechas, pero esto no le priva de sesiones poéticas en las que se entusiasma cuando le mencionan la inmensa victoria que alcanzará su gran ejército (...). No tuve imagen de al-Mu'tamid en Agmat mientras no impresionó mi mente el cliché de Don Quijote postrado en su lecho, esperando la muerte, en la tiniebla del fracaso: También al-Mu'tamid anhelaba la muerte en la penumbra de su cautiverio (Viguera, 1975: 161)
\end{abstract}

Esa herencia andalusí perdura en el cristiano español del Imperio, que según Mu’nis

se levanta y construye un imperio que casi abarca el mundo (...). Europa no le sacia y cruza el Océano hacia un Nuevo Mundo que construye. Y al cabo regresa a su patria, claudicando, y se encierra en sí mismo, arroja las armas y se agazapa en el centro de la península, sin más fruto, después de tanto esfuerzo, fatigas y renuncias. ¿No es éste Don Quijote? ¿No es alMu'tamid? (Viguera, 1975: 162).

Mu'nis ve a Sancho Panza como hombre juicioso que representa la realidad; sigue a su amo por afecto, y le aconseja; pero con el tiempo se le contagian sus fantasías y abandona esa realidad, aunque al final le vence la razón. Estos rasgos también están presentes en el prototipo de español que el autor ha conocido y en el que ve la síntesis de ambos personajes cervantinos:

$\mathrm{Su}$ vida es bisectriz de la ponderación y la inconsciencia, de lo real y lo ilusorio. Mitad filósofo, mitad aventurero. Medio Quijote, medio Sancho (Viguera, 1975: 163).

Según él, Don Quijote pronto va a sustituir en el favor del público a los héroes victoriosos de las anteriores novelas de caballería, como Bernardo del Carpio, Amadís de Gaula o el Cid Campeador, pues sólo reflejaban un aspecto del alma hispana:

Aquellos héroes no se asemejaban a los españoles sino en una vertiente; son aventureros sólo (...). Marchan de victoria en victoria, de gloria en gloria. Casi nunca la rueda del destino les traiciona. Don Quijote, en cambio, es hombre de suerte adversa, aunque Dios le haya dotado de altas intenciones, de firmeza y paciencia en las desgracias (...). Esto distingue a Don Quijote de los otros héroes y esto le acerca al alma hispana, pues el español está seguro de que el destino le es contrario siempre, de que, si no fuera por los hados, habría alcanzado tantos logros como todos los otros, convencido de que es de los mejores hombres del mundo, mejor dicho: el mejor (Viguera, 1975: 164).

Mu'nis considera que la ironía que tiñe la vida de Don Quijote será un rasgo permanente del alma hispana, como se revela en escritores y artistas de todos los tiempos Cervantes, Ortega o Murillo-. Considera la ironía, rasgo que le es muy querido, como la médula del juicio y del sentido de la filosofía del español. Cree encontrar las raíces de esa ironía en los hispano-musulmanes, para los que cualquier defecto de hombre humilde o poderoso era ocasión para la sátira, aportando varias anécdotas que así lo demuestran. Según él, eso no le ocurría al hispano antes de su contacto con los árabes:

El andalusí fue hombre irónico. Nada admiraba, y su lengua no perdonaba nada. Los hispanos no eran así antes del trato y convivencia con los árabes. En las obras de los autores hispanolatinos, Séneca, Quintiliano, Marcial, Lucano... apenas encontramos burla o sátira; éstas son resultado de su mezcla y fusión con los musulmanes (...). Por eso gustan de Cervantes, por eso aman su Quijote y su Sancho, su Rinconete y Cortadillo y otros personajes sarcásticos que 
modeló la mano del artista creador, haciéndolos símbolo de la burla perenne de la vida (Viguera, 1975: 167).

Y, mencionando de pasada las referencias que hace Cervantes al Hamete Benengelí, concluye su ensayo afirmando que "Cervantes escribió influido directamente por el alma andalusí" (Viguera, 1975: 168).

Por último, en 1957-58, Raya' al-Naqqaš (n. 1935?) -que tampoco tiene relación directa con la cultura española- se pregunta “¿Por qué hemos puesto el veto a Don Quijote?” ( $\mathrm{Li}$ mada nusadir Dun Kišut? $)^{7}$, ensayo sobre la censura que se hizo a dos pasajes del libro de Cervantes, ejemplificando las dificultades de entendimiento a nivel intercultural cuando se mezclan, sin dialéctica, tiempos y formas, juicios y complejos (Viguera, 1975: 145). AlNaqqas comienza su ensayo con dos anécdotas sobre el prestigio del Quijote y de su autor en la vida europea: una de Luis XIV, que envidiaba a un cortesano que había aprendido castellano por poder degustar directamente la amenidad y el arte de Don Quijote, y otra de Felipe II que, al ver a un estudiante estallar en risas al leer un libro, dijo que o estaba loco o estaba leyendo Don Quijote. Luego hace un breve repaso a la azarosa y fracasada vida de Cervantes, haciendo hincapié en su participación en la batalla de Lepanto, fruto del resentimiento europeo contra los musulmanes que compartiría Cervantes, así como en su tardío éxito literario que no impidió su triste final. A continuación analiza los principales personajes del Quijote, que considera arquetipos humanos, relatando alguna de sus aventuras. Así define a Don Quijote:

El primero encarna todos esos impulsos de fantasía, sueños e idealismos que hay en el alma humana; quiere aniquilar todo el mal de la tierra, corregir lo perverso. Pero sus sueños chocan con la dura y amarga realidad; él persevera y sigue su combate, pues está convencido de su misión, y tales seres soportan toda suerte de adversidades siempre (Viguera, 1975: 171).

Tras narrar el episodio de la liberación de unos presos a los que pide que lleven las rotas cadenas a su inventada Dulcinea, pero que, en lugar de agradecerle su liberación, acaban moliéndole a palos, expone las diversas interpretaciones que se han hecho de su personalidad:

Para unos, es el modelo de la locura; para otros es la imagen de los sueños que se desatan, en libertad equilibrada; o encarna el idealismo, chocando con el horror y la miseria que puede contener la realidad; otros lo ven como el prototipo de la índole hispana, que sueña sin poder realizar aquellos sueños, que traspasa los más lejanos horizontes para retroceder luego frustrado a un angosto retiro, tal como sucedió con el imperio español de América, después de descubrirla (Viguera, 1975: 172).

Y acaba la interpretación del personaje con unas palabras de Unamuno, en cita no literal como señala Viguera:

Don Quijote perdió su juicio para sernos un ejemplo inmortal de generosidad espiritual. A su pueblo ofreció el más grande sacrificio: su razón. Su fantasía iba llenándose de bellos desatinos, mas Don Quijote entendió por verdad lo que es sólo hermosura (Viguera, 1975: 172).

La figura de Sancho Panza la interpreta así al-Naqqaš:

\footnotetext{
${ }^{7}$ Ensayo incluido en Voces airadas en torno a la literatura y la crítica (Aswat gadiba fi l-adab wa-l-naqd, 195758), reimpreso en 1970 (Viguera, 1995: 14). Traducción completa de este ensayo en Viguera (1975: 168-177).
} 
Sancho, siguiendo a Don Quijote, figura la razón que intenta retener el ideal de perfección absoluta de su amo. Sancho, por ejemplo, advierte a Don Quijote: “Amo mío, ¡hasta dónde ha llegado el desvarío de tu mente!", pues lo tenía por loco que despreciaba el dinero y dejaba de lado la riqueza por perseguir un propósito abstracto que a Sancho no placía, ya que su gusto estaba en cosas materiales: comida, dinero o poderío (Viguera, 1975: 172).

Al igual que Mu'nis, también señala como rasgos más importantes de esta obra "su sentido del humor y la ironía, sin sombras de rencores o amarguras, pues Don Quijote de todo satiriza, incluso de sí mismo" (Viguera, 1975: 175). Y el resto del ensayo lo dedica alNaqqas a criticar la anunciada confiscación de la traducción del Quijote realizada por alAhwani en 1957 por contener dos pasajes ofensivos: uno contra los árabes, donde los tacha de mentirosos en general, y otro contra el Islam, donde también llama mentiroso al Profeta. Achaca estos pasajes al fanatismo anti-musulmán que dominaba en España en la época de Cervantes, aunque destaca la valoración que luego se haría de la fecunda fusión que se produjo entre la cultura árabe y la europea. También justifica que Cervantes incluya este comentario anti-árabe de uno de sus personajes, pues correspondía a la realidad de la época, que aún guardaba recuerdos de las largas contiendas habidas con ellos. Además critica la rigidez mental de los censores, pues piensa que se deben conocer completos los más importantes textos literarios aunque contengan opiniones con las que no se esté de acuerdo, para saber también la opinión que otros tienen de ellos. Y, tras exponer algunos casos de revuelo respecto a obras literarias que contenían prejuicios anti-árabes o anti-musulmanes, al-Naqqaš critica este veto que, por esos breves pasajes, impediría a los árabes el acceso a tan universal obra de arte, pues la lectura de Don Quijote, dice, "puede darnos más de lo que puede quitarnos" (Viguera, 1975: 177).

Viguera (1999: 10,17) concluye su segundo estudio sobre el tema resaltando la calidad y la riqueza interpretativa del conjunto de informaciones, perfiles y sensaciones que ofrecen estos ensayos egipcios de los años cuarenta y cincuenta, que serán la vanguardia introductora del personaje en el ambiente literario árabe, contribuyendo así a arabizar arquetipos universales en su voluntad de apertura cultural. Martínez Montávez (1992: 189) matiza las diferencias entre ellos: mientras Mu'nis replantea lo que puede haber de andalusí en la obra de Cervantes, el objetivo de los otros ensayistas es resaltar diversos aspectos de la egregia y plural dimensión simbólica universal de Don Quijote.

La labor de estos ensayistas y de otros -como al- ${ }^{\mathrm{C}}$ Aqqad (1889-1964) que también estudió a Cervantes- va a permitir que la figura del Quijote sea convocada con insistencia por la literatura árabe de creación, que asumirá sus simbolismos con notable cantidad y hondura en las décadas siguientes (Viguera, 1995: 10-11).

Así, en la década de los sesenta el poeta egipcio Nayib Surur (1932-1978) recurre a Don Quijote $^{8}$ para expresar sus profundas frustraciones. Obligado a un doble exilio -de Moscú, donde estaban su mujer y sus hijos, y de Egipto, al que no podía volver por orden de Náserdedicará varios poemas a Don Quijote, como "El jinete del último tiempo" (Faris ajir alzaman, 1975). Pero tal vez en un texto anterior y precursor de los de la segunda etapa, Hacer imprescindible lo que es necesario (Luzum ma yalzam, 1964) ${ }^{9}$, sea donde mejor

\footnotetext{
${ }^{8}$ Martínez Lillo (1990: 310n22) señala que Surur transcribe "Dun Kijut", por lo que no se descarta que conociera la lengua castellana.

${ }^{9}$ Traducción completa de la obra por Santiago Alba y Javier Barreda (vid. Surur, 1993).
} 
exprese su hastío y rebeldía contra todos los sistemas políticos. Se trata de un largo poema, compuesto en su exilio en Budapest, en que el hilo conductor será su diálogo con Don Quijote, luchador de causas perdidas que encarna, para Surur, las virtudes del auténtico caballero. El poema, en que amada y tierra se identifican, comienza así:

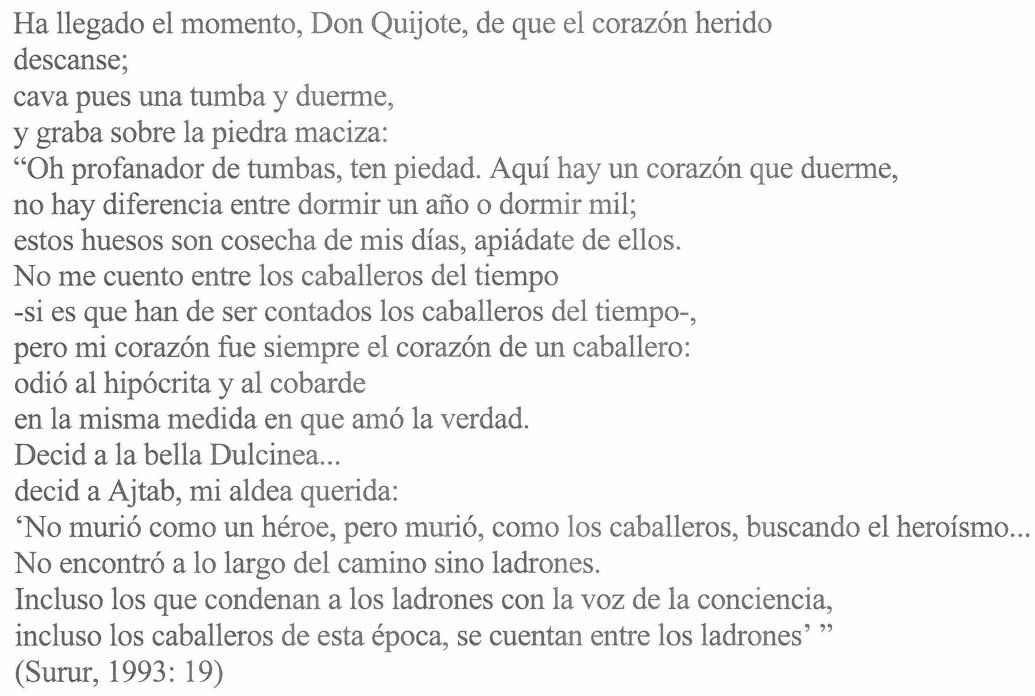

En este diálogo con Don Quijote, Surur le pide que no enmudezca, porque el silencio es el infierno (1993: 21), y porque "murieron los hombres de honor. Murieron y vivieron los corruptos, los explotadores" (1993: 37); por ello le dice: "Grita, quizás tu grito febril abofetee algún oído" (Surur, 1993: 117). Y también se pregunta, en una clara identificación entre autor y personaje:

Quijote, ¿quiénes somos nosotros entre los hombres?

¿Profetas

o necios?

¿O es que el secreto de nuestro tormento es un mal incurable...

un mal llamado orgullo?

Quijote, sé paciente como lo fue Job en la desgracia (Surur, 1993: 69).

$\mathrm{Y}$, aunque sabe que "quien habla honestamente resulta molesto a los contertulios" (Surur, 1993: 121), ve en Don Quijote un símbolo de esperanza:

Y sigues sin esperanza.

¿Sin esperanza?

¿En qué punto del terrible viaje perdiste la esperanza?

No, no desesperaste, sino que confiaste en el destino... Si hubieses desesperado,

si no hubieses sido más fuerte que la desgracia, i¿cómo habrías llegado?! (Surur, 1993: 120).

Este diálogo con Don Quijote lo va mezclando Surur con diálogos con otros personajes, como al-Macarri, célebre poeta árabe del s. X ciego y rebelde al que apoda "el Quijote de Macarra" (1993: 105): 
- Eres un Quijote.

- ¡Te lo ruego! ¿Quién es ese Quijote?

- Un poeta que se expresa en todas las épocas.

- ¿Y es ciego?

- Al contrario, clarividente como la conciencia, valiente como la conciencia,

y desgraciado como la conciencia...

en un tiempo hueco por ambos lados,

desprovisto de conciencia.

- Descanse en paz él y nosotros.

"Triunfó la mentira desde el principio de los tiempos y murieron de cólera

los sabios" (Surur, 1993: 51-42).

Para Santiago Alba (en Surur, 1993: 10), Surur no está loco, sino que "la nostalgia del caballero le espolea en un rencor furioso: sólo hay caballerosidad en el exilio de la realidad, sólo hay caballerosidad, por tanto, contra la sociedad"; como Don Quijote, Surur "permanece exiliado de la realidad y arremete contra ella sin esperanza de triunfar"; "ése es su privilegio, puesto que esa realidad es mala; pero ése es su castigo, porque no hay otra realidad". Así el poeta/Quijote será "el exponente de una época maldita que es y sigue siendo, por desgracia, la de todos".

La derrota de Junio de 1967 en Palestina va a repercutir en todas las esferas de la vida árabe contemporánea. Según Martínez Lillo (1990: 308-309), la derrota provoca en los literatos sentimientos de pérdida, angustia, soledad, desesperación o tristeza; pero, a la vez, surge la necesidad de buscar "elementos" fuertes para hacer frente a la adversidad y vencerla; y algunos de esos elementos los buscan en el "paraíso perdido" de al-Andalus, en España, y se topan de nuevo con la figura de un "caballero andante (...) que lucha a favor de la justicia y del bien en un mundo maleado, adulterado y eminentemente materialista".

Las secuelas del desastre del 67 son descritas de inmediato por el poeta iraquí Aršad Tawfiq, en su poema "Don Quijote" (Dun Kišut $)^{10}$, rico cortejo de imágenes donde el autor rechaza los resultados del mal quijotismo, mientras invita a resucitar al quijotismo bueno (Viguera, 1999: 17). Tawfiq se identifica con el desventurado soñador, a la espera de un nuevo amanecer, de un mundo como el que anhelaba el universal personaje:

Sigues, Don Quijote, en la orilla perdida,

la espera cubriendo tu mirada, sus velas, sobre la costa, en el confin del mundo, muertas de recuerdos.

Te ríes de tu sombra, que se derrumba, ocre esperanza, sobre el muro, maldiciendo -Ícaro, en su pasión y Simbad- el amor y los mares. Quijote, esa lanza es leyenda que vive de los sueños, no del día, $\mathrm{y}$ tu roto costado... una guitarra

\footnotetext{
${ }^{10}$ De su diván La estrella y el derviche (Al-nayma wa-l-darwiš, 1967).
} 
que llora por el enamorado y el viajero.

¡Qué infortunio! ¡Fruto de nuestros sueños!

Volviste lacerado por tu yerro

y escondiste en el mar ... canciones de amor,

verdes de sueños... y una flor de granada.

Dulcinea, ojos como

perlas cristalinas de los mares,

ya estás en la orilla muerta,

la espera cubriendo tu mirada.

Al caer quedó una tonada verde

que tiembla en tus heridas... llama dulce.

¡Poeta mío! Canta que en tus palabras

renacerá Don Quijote... y despuntará el día.

(Trad. de $\mathrm{M}^{\mathrm{a}}$ L. Cavero, en Literatura iraquí contemporánea, 1977: 161-162).

Según Viguera (1995: 11), en la década de los setenta, el símbolo quijotesco resulta adecuadísimo para que el literato árabe recurra a él como expresión de la absoluta contradicción, como figura de inconveniente idealismo, e incluso de idealismo fomentado con aprovechada intención. Un ejemplo sería el poeta sirio Nizar Qabbani (1923-1998) buen conocedor de España, donde residió de 1962 a 1966 como consejero de su embajadapues alude a Don Quijote en este sentido; tras la derrota del 67, su escritura se transforma “cambia la rosa por el puñal" (Martínez Montávez, 1977: 27)- y pasa del tema amoroso al político, con un alto grado de autocrítica. En su largo, violento y discutido poema Apuntes en el cuaderno de la nueva derrota (Hawamiš calà daftar al-naksa, 1968), el símbolo adquiere una connotación negativa de ineficacia, llevado por su deseo de hacer caer las máscaras, pues dice refiriéndose a la Guerra de los Seis Días:

No es raro que perdiéramos la guerra...

Porque entramos en ella

con la innata retórica que posee el oriental,

con ese "quijotismo" que no mata una mosca

(Trad. de Martínez Montávez, 1975: 20).

Continuando con esa derrota, añade en el poema octavo de Los actores (Al-mumattilun, 1969):

Ya la guerra de junio terminó.

Y parece que no ha ocurrido nada:

Delante de nosotros

siguen los mismos rostros, y los ojos.

Han vuelto las censuras,

los censores,

y aún los "Don Quijotes" representan"

(Trad. de Martínez Montávez, 1975: 32).

$\mathrm{Y}$ en El interrogatorio (Al-istiywab, 1969) reafirma su condena a la ineficacia árabe usando el símil de los molinos de viento:

He pasado veinte años

como un montón de paja sobre la alfombra roja.

Tragándome retóricas, metáforas y alquitarados versos, palabrería vana. 


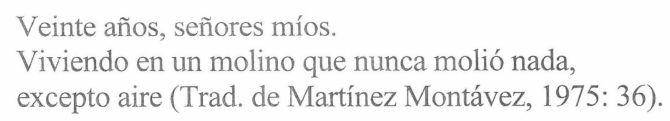

Uso similar hallamos en una de sus Cien cartas de amor (Mi'at risalat hubb,1970), donde Qabbani se dirige a una amiga usando la referencia a Don Quijote de tal modo que puede resultar "algo violenta o abrupta a nuestros oídos", como señala Martínez Montávez (1977: 30):

En tu última carta me dices:

"He perdido la guerra contigo".

Mas, ¿cuándo entraste en guerra, amiga mía, para poder perderla?

Tú luchas a la manera de Don Quijote.

En el lecho tumbada,

atacas los molinos

y combates al aire. (...)

Pequeño Don Quijote,

despierta de tu sueño (Trad. de Martínez Montávez, 1977: 30).

En similar sentido clama el poeta palestino Samih al-Qasim (n. 1939) en un fragmento del poema "Porque nosotros" tras la debacle del 67:

Me doy cuenta de que vamos a morir,

porque nosotros... no dominamos la técnica del combate,

porque nos hemos vuelto Quijotes,

porque... nos morimos de hambre (Trad. de Martínez Martín, 1972: 166).

También en tono semejante, aunque con mayor ternura, aparecen los personajes cervantinos en la prosa poética del palestino Mahmud Darwiš (n. 1942), y seguramente también en sus versos. En Memoria para el olvido (Dakira li-l-nisyan, 1987), centrada en Beirut durante el duro asedio israelí de 1982, habla de un escritor emigrado instalado en su casa, al que llama "S.", que se había unido a la Revolución, convirtiéndola en su hogar, su familia, su identidad y su patria. Y Darwiš compara a "S." con Don Quijote y Sancho:

S. disfruta con la guerra. Sólo en ella puede desbocar toda su reprimida violencia (...). En ella encuentra, en fin, esa encrucijada de vientos en que ser espada lozana y fresca para batirse con enemigos que pasaron (...). Echa mano a la pistola y jura: ¡Venceremos! ¡Les haremos morder el polvo!, aunque en realidad no sepa si vencerá o no. El chico de las batallas perdidas. El chico anti-aritmética. Las justas y desafíos son lo único que de verdad le interesa. S. ocupa una posición intermedia entre Don Quijote y Sancho. Transforma a los enemigos en arquetipos al alcance de la mano. Se inflama de coraje, se hincha, se estira, se tensa, y golpea lo primero que encuentra, para contenerse a continuación secundando la sapiencial ponderación de [su amigo] Y., el buscador de la filosofía en el canto, el enemigo del lirismo. A falta de agua, carne y mujeres, S. encontró a "la de sin par belleza": ¡Mucho cuidado, querido S.! ¡Que ella es obra de tu antepasado Don Quijote! ¡Que es pariente de las lagartijas que salen en la canícula entre los resquebrajados surcos del alma sedienta! ¡Que es su voz el ulular de los matojos que despuntan en los sequedales de las ruinas! Pero él había dado un paso irreversible en su proceso de autotransformación, había logrado entrar de lleno en la comedia para lograr lo que le faltaba como auténtico caballero andante: una mujer. ¿Dónde andará ahora S.? ¿Lo habrá cazado la metralla o habrá cazado él una gallina para aquella "de sin par belleza"? (Darwish, 1997: 95-96). 
Pero la mayoría de los literatos árabes ven en Don Quijote un símbolo de esperanza. El novelista sirio Hani al-Rahib (1939-1982), muy comprometido con la problemática del mundo árabe actual, publica en 1978 el relato "Don Quijote" (Dun Kišut) ${ }^{11}$, donde usa al personaje para expresar sus propuestas de solución para los graves conflictos en que ese mundo está inmerso. El protagonista de este relato alegórico es un moderno Quijote, un héroe obsesionado por "las cuestiones del Imperialismo, el Subdesarrollo y la Balcanización". Aunque va en bicicleta y maneja instrumentos de la moderna tecnología, el móvil de su lucha por un mundo mejor sigue siendo el amor, a una mujer y a una patria; también le acompaña un fiel escudero, que no le entiende pero cree en él. Este Quijote es un intelectual que vive en un mundo infecto y emplea su elocuencia para plantear los problemas, despertar a la gente y hacerla participar en su solución. El relato comienza con Don Quijote hablando a su amada Umayma/Dulcinea sobre el amor que les une, la realidad en la que viven y el ideal de cambio que persigue:

Umayma, has de saber que el amor es una perla rara en estos tiempos, pero nosotros, los dos, la poseemos. Para ser completamente felices y vivir en un ambiente de sinceridad y libertad, envidiados por todo el mundo, no tenemos más que echar las moscas de nuestra casa, matar las chinches y las cucarachas y barrer los desperdicios que se han ido acumulando en la calle. Mientras tanto, y según vayamos avanzando en esta importante e histórica tarea, me dedicaré por completo a ti, con todas las energías y con todo el amor que bulle en mi corazón. Convertiré el lugar en que vivimos en un jardín exuberante donde se puedan agitar tus trenzas negras con las ráfagas del aire puro, tamizado por rayos de sol. Caerá la lluvia y las estepas árabes se cubrirán de hierba, se multiplicarán los peces en nuestros mares, y en el gran desierto se levantarán factorías (Trad. de Ramos, 1999: 21).

$\mathrm{Al}$ amanecer, mientras el sol va subiendo por encima de las montañas y su mundo dominado por las antenas de televisión, Umayma -diminutivo de umma, "comunidad" o "patria"- está dormida y suena en el transistor una simbólica canción sobre el despertar de esa patria, que se repite en tres ocasiones a lo largo del relato:

Tú que pasas con sigilo/a la vera del molino/cuando el agua está cortada,/ temiendo que las aspas giren /y despierte la muchacha (Ramos, 1999: 21, 22, 25).

Por la tarde, Don Quijote está con su amigo Yundub/Sancho en un café, un espacio que aparece a menudo en sus obras como espacio de la juventud estudiantil de Damasco, y le habla de los problemas del mundo árabe y sus soluciones, con ejemplos muy simples:

Yundub, has de saber que el Imperialismo, el Subdesarrollo y la Balcanización son cuestiones que me tienen obsesionado. A veces pienso que (...) vencer estos problemas no debe ser más difícil que acabar con las moscas, las chinches y las cucarachas, ni tampoco más que barrer los desperdicios que se han acumulado en nuestras calles. Nuestro principal y fatal error consiste en haber dado crédito a la propaganda enemiga, aceptando ingenuamente que estas tres cuestiones constituyen una sola, unidas en cohesión orgánica y letal en sus tres aspectos, cuando la realidad es que para matar chinches hay un producto específico, para matar moscas hay otro, y otro más aún para las cucarachas, y que sería ilógico rociar a estas criaturas con

${ }^{11}$ Relato incluido en Los crimenes de Don Quijote: colección de cuentos (Yara'im Dun Kišut: Maymu 'at qisass 1978). Texto árabe del relato y traducción de Ana Ramos, en Don Quijote (1999: 21-27). Estudio del relato, en Ramos (1978: 2-6). 
todos los productos a la vez, porque nos ahogaríamos nosotros antes de que ellas murieran. Existen múltiples resquicios en estas tres cuestiones por los que poder introducirnos para asestar nuestro golpe, demostrando al mundo entero que el Imperialismo, el Subdesarrollo y la Balcanización no son más que simples molinos de viento, que podemos poner en movimiento o detener a nuestro antojo (Ramos,1999: 22-23).

Don Quijote vuelve a escuchar la canción en su transistor; el entusiasmo se va apoderando de él, y sale con Yundub del café. Y al atardecer los caminos rurales desérticos se llenan de bicicletas, conducidas por hombres que llevan detrás a una mujer, que se dirigen hacia el lugar en que están los molinos de viento, es decir, los obstáculos que se ponen en su camino. Don Quijote, que va en su bicicleta con Umayma, le dice:

- Umayma, has de saber que para mí los molinos de viento constituyen un símbolo permanente. Representan, a diferentes escalas, la lucha con la que nos hemos comprometido. Si están parados, nuestros problemas terminan, pero cuando se mueven... ique Dios nos asista! (Ramos, 1999: 23).

Pero Umayma no entiende el simbolismo de su discurso, porque ella, como mujer/patria dormida, sólo piensa en el aspecto material:

- No acabo de comprenderte. Se supone que, cuando los molinos se paran, no hay harina, y que cuando se mueven tenemos harina.

- Tienes razón. No has entendido nada. Yo hablo de molinos de viento, y tú, de simples molinos (Ramos, 1999: 23-24).

En otra bicicleta va Yundub con Ummiya/Teresa -que puede significar "analfabeta", "ignorante", y representa al pueblo apegado a sus necesidades cotidianas-. Yundub tampoco entiende a Don Quijote, pero le considera un genio, y espera que se produzcan grandes cambios cuando éste entre en acción. Llegan todos al lugar, bajan de las bicicletas y rodean los tres molinos de viento. Don Quijote saca una moderna varilla metálica de su cartera y hace con ella una especie de lanza para abalanzarse contra los molinos, mientras le explica a Umayma lo que no había entendido:

Ahora comprenderás, amada mía, por qué el molino de viento que no se mueve no hace daño a nadie. Verás cómo permanecerá en silencio sin reacción alguna, cuando le hostigue con este producto del mundo de la tecnología. Y ello porque la tecnología está emparentada con el molino de viento y comprende su mensaje (Ramos, 1999: 25).

En efecto, lo hace y sólo sale del molino un chirrido. Guarda la varilla, y se dispone a subir al molino, para adueñarse de él. Apoyándose en Yundub, que ha ido repitiendo a Ummiya todo lo que decía Don Quijote, se encarama en lo alto del molino, mientras sus camaradas/el pueblo se suben a los otros dos, ayudándose unos a otros. Una vez allí, este Quijote se introduce entre las aspas -símbolo de los tres problemas mencionados-, y entonces se produce la sorpresa: las aspas empiezan a moverse, cada vez con más rapidez. $\mathrm{Y}$ a medida que giran y su cuerpo se va fundiendo con ellas, aumenta su placer, mientras cree oír de nuevo la canción que tanto le gustaba:

Sintió su dominio sobre las aspas y cómo sus esfuerzos por utilizarlas a su antojo habían sido coronados por el éxito. (...) Experimentó la plenitud del poder y de la embriaguez, y le embargaron sentimientos de gloria, pues éste era un hecho grandioso y aquél un momento histórico. Había expuesto su vida, esforzándose por abarcar las dimensiones de una experiencia única. (...) Don Quijote comprendió que las aspas se habían fundido finalmente 
con su cuerpo y que el infinito estaba ahora bajo su poder. (...) Su conciencia se había liberado hasta el punto de no sentir pánico cuando por efecto de la fuerza centrífuga su cuerpo se proyectó al vacío, subiendo por encima del sol, que desapareció de su vista. En el vacío veía colores que se alejaban y se acercaban y comprendió en aquellos momentos que había experimentado la vida en toda su realidad. Emocionado, veía acercarse y alejarse los rostros perplejos de la gente, que, apilada, formaba una masa compacta de color plomizo que no paraba de moverse alrededor de los tres molinos de viento. Cerrando los ojos, se entregó a las aspas de la victoria.

La multitud presenciaba sin aliento el espectáculo, cuando las mujeres, con ojos desorbitados, se postraron de rodillas al ver a Don Quijote caer (Ramos, 1999: 27).

En este relato al-Rahib expone la situación de la juventud universitaria de Damasco, que no está contra el progreso, pero está enredada en un caos del que no puede salir y se evade en la bebida, el sexo o jugando al tric-trac en los cafés (Ramos, 1978: 2).Y será un nuevo Quijote árabe quien los movilice y les haga participar en el cumplimiento de sus sueños, pues los problemas de su mundo han de resolverlos ellos, actuando de forma solidaria.

En 1974, otro narrador, el iraquí Yalal al-Qaysi (n. 1938), escribe su relato "Sueños del caballero triste, Don Quijote"12 (Ahlam al-faris al-hazin Dun Kišut) publicado en Al-Adab. Según Viguera (1995: 13-14), el relato se inicia recurriendo, significativamente, al lema "La lógica ha de crecer, hasta asumir la ilógica", lo que da idea de los propósitos de alQaysi al usar el símbolo de Don Quijote: por una parte, manifestar la contradicción existencial, que finalmente el tiempo resuelve, ridiculizándose la agonía del conflicto; pero... ¿y antes de que todo quede relativizado? Al protagonista, un hombre pensativo, ponderado, con ribetes de soñador, le gusta leer el Quijote:

En primavera salía, una o dos veces por semana, fuera de la ciudad, con una novela o un libro de teatro, y enfilaba la carretera principal, hasta un pueblecito de casas terrosas, ceñidas de morera y nogal. Allí, contemplando alcores, valles verdecidos, flores y vegetación nueva, embebía el alma de la primavera (...). Una tarde, acabadas las cien últimas páginas de Don Quijote, salió de la aldea, caminando largo trecho, repensando penas, sueños, fracasos del noble Caballero. Aun riéndose de algunas desventuras, le asaltaban las congojas: "¡Pobre, hasta sus sueños eran batallas! ¿Por qué? ¿Cómo a este desgraciado ocurriósele volver justo al mundo? ¿De dónde aprestaba este soñador consumido toda aquella voluntad acerada, todo aquel firme temple, para las fantasmagóricas posturas que emprendía? ¿O lo hacía a pesar suyo?..." (Viguera, 1995: 13).

Luego el protagonista, dormido, tiene sueños en que se mezclan los de Don Quijote, pero al-Qaysi hace que sea captado por un platillo volante de seres de un planeta lejanísimo que han alcanzado tan fabuloso desarrollo que sólo podemos imaginarlo, aunque algunos idealistas, como Don Quijote, hayan intentado realizarlo anticipadamente, acarreándoles tragedias e incomprensiones. Según Viguera (1995: 13), la moraleja de este relato, donde al-Qaysi analiza y muestra la conjunción de formas pasadas de la civilización humana, es que también nuestra civilización actual será superada, y que, sin embargo, es preciso actuar en consonancia con la realidad del presente. El que así no lo hiciera Don Quijote, nos lleva a admirarle y a compadecerle al mismo tiempo. Al final, al-Qaysi despierta al protagonista de su sueño, lo devuelve a la realidad. Pero hay un último detalle indeciso, que simboliza nuestra perpetua confusión entre lo real y lo ideal, pues el protagonista "saltó al último

12 Traducción completa del cuento en Viguera, 2003. 
autobús que llevaba a la ciudad... Recordó entonces que había dejado la novela de Don Quijote en aquel complejo platillo volante" (Viguera, 1995: 14).

En 1979 el libanés Yusuf al-Jal (1920-1980), en una de sus Epístolas a Don Quijote (Rasa'il ilà Dun Kišut, 1979), le considera "un héroe único, un tanto contradictorio, pero firme en sus ideales; un héroe que está siempre sobre su corcel 'tanto en el despertar como en el sueño" " (Martínez Lillo, 1990: 309-310). Según Martínez Montávez (1992: 261), en este texto en prosa, pero con lenguaje poético, al-Jal se sitúa en un clima de desaliento, de derrota física y moral, que exige buscar nuevas opciones y salidas. Las diez epístolas, dirigidas al caballero de causas imposibles y sostén de desvalidos, están escritas más desde la serenidad contenida, y quizás la desesperanza, que desde el grito, y con ellas al-Jal quiere expresar el desgarro y confrontación interna que pasa su país en plena guerra civil. En una de ellas se dirige a Don Quijote para explicarle sus luchas, usando el mismo tono irónico que caracteriza la novela de Cervantes:

Desenvainamos nuestras espadas contra la ciudad de porcelana, levantamos la máquina del asedio. Allí estuvieron los cojos, los mudos y los ciegos, todos los que tenían alguna deformidad. Combatimos hasta rompernos los dientes. Y seguimos combatiendo, oh, caballero, porque combatir es nuestra gran afición. En los ratos de ocio removemos los desiertos buscando un enemigo (Trad. de Martínez Montávez, 1992: 262).

Ya en los años ochenta, el poeta palestino Muhammad al-Qaysi (n.1944), marcado por el marchamo del destierro, le dedica el poema "La morada de Don Quijote" (Manzil Dun Kišut), en su Diwan: Moradas en el horizonte (Diwan: Manazil fi l-ufuq, 1984), en clara alusión a la dura existencia palestina y las falsas promesas del Partido Laborista israelí:

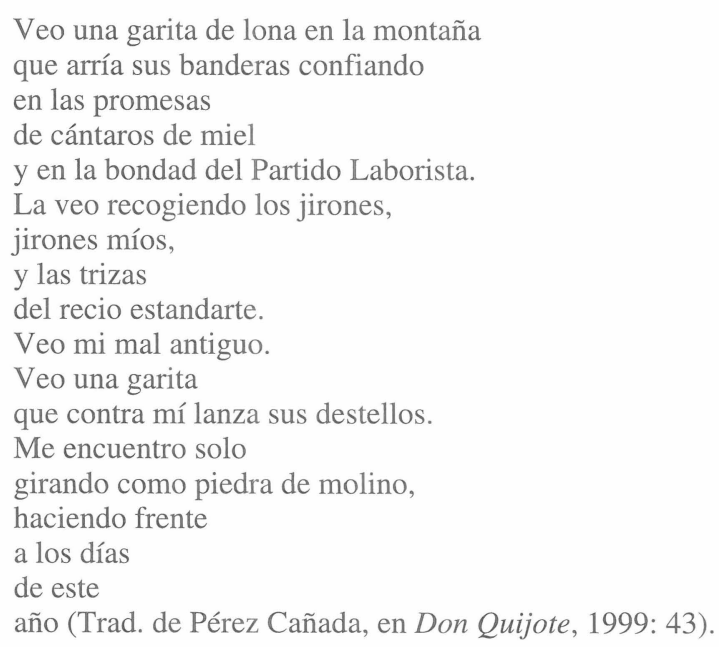

Y en los años noventa, el narrador y poeta sirio Ibrahim Jalil (n. 1944) publica el poema "Don Quijote" (Dun Kišut) en Al-Ra'y (n' 1, 1999: 11), donde emula el modo de dirigirse el personaje a su amada Dulcinea, en busca de apoyo a su continua lucha:

A ti, luna de los tiempos

y señora mía,

llego desde mis reales 


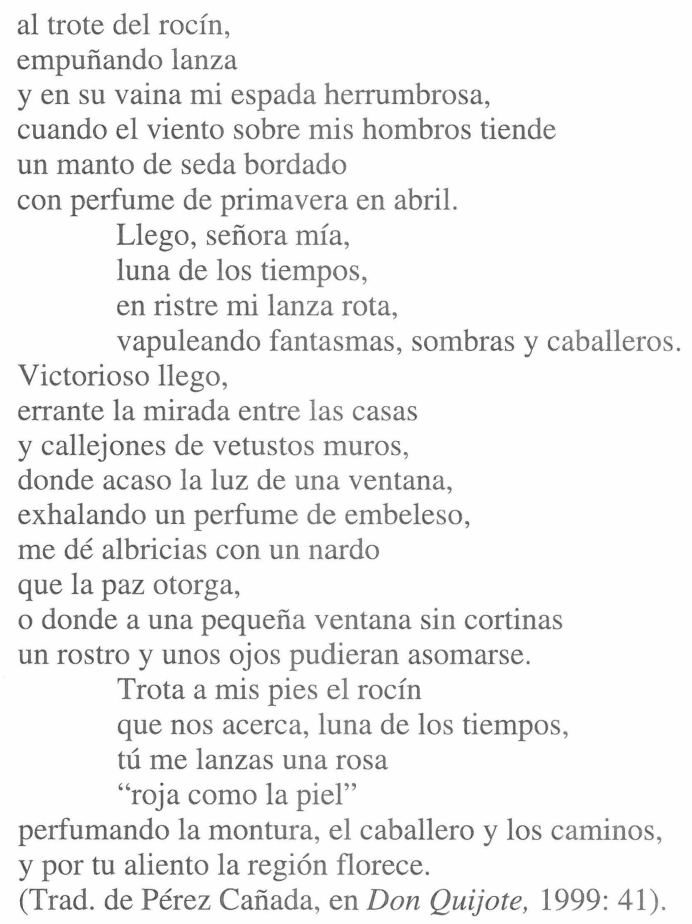

El eco de la figura del Quijote también llega a la literatura del Magreb. El narrador marroquí Muhammad Šukri (1935-2003), lector tardío pero infatigable, era un gran admirador de Cervantes, al que leía en español (Chukri, 2002: 3,5). Pensaba que Don Quijote había aplastado con su fama a Cervantes, del mismo modo que su Pan desnudo le había aplastado a él, ya que por más que escribía todos le conocían por esa obra.

${ }^{\mathrm{c}}$ Abd Allah Hamadi -profesor argelino de la Universidad de Constantina- residía en España en 1975 cuando escribió su largo poema "Don Quijote se pone en camino", publicado en la revista Almenara y dedicado a Vicente Alexandre. Según Viguera (1995: 11-12), Hamadi recurre a este símbolo para expresar su insatisfacción con lo existente, resaltando su capacidad en la lucha desigual, su afán de justicia, su admirable idealismo. Es un Quijote soñador y peleador de futuro. El poeta siente que acaso Don Quijote esté muerto para siempre, y le incita a regresar mencionándole la larga serie de ultrajes que les perturban. Y además siempre pide a Sancho Panza que no le abandone, pues el idealismo ha de tomar referencia de la realidad. De este largo poema entresacamos los versos en que mejor se identifica Hamadi con Don Quijote:

¡Venga, mi Rocinante, el que suele rodar como un guijarro!

¡Venga, mi rodela, mi espada y esa lanza tallada en colmillos de tigre de feroces junglas!

¡A mí! que saldré a caminar,

a derribar el molino ruidoso,

y arrancaré de raíz esos vientos que en mis oídos aúllan, 
que perturban el descanso de mi cementerio blanco,

la siesta bajo la frondosidad desnuda,

el beso del azahar en mi marchita primavera,

la siega de espigas de mis bancales yermos (...).

¡Sancho, mi apoyo, mi compañero!

Tú eres parte de mí mismo, tú, mi propio camino (...).

Con una luz rojiza voy en pos de un imposible (...)

¡Adelante!

Toca el mar con tu varita mágica,

que, con mi espada y mi escudo,

Rocinante y yo prenderemos las espigas del viento

y entonaremos para ti el himno de la tierra:

Así vamos, amigo mío, compañero,

lamiendo la infinita planicie del mar que hierve, se algazara y se rebela (...)

Don Quijote soy, el profeta embozado, tal vez esa tortuga que, por burlar los colmillos del tigre,

detuvo un instante la luz de la jungla.

Don Quijote, sí, amigo mío, que cabalgó su locura

para ofrecerte el sueño en una casida

(Almenara, $\mathrm{n}^{\circ}$ 9, 1976: 203-207).

Pero será de nuevo en Egipto donde más abunden las referencias a Don Quijote en esta segunda etapa. Un ejemplo de la alta valoración en que se tiene a Cervantes en Egipto nos lo proporciona el periodista y narrador egipcio Yamal al-Gitani 1945), que se alimenta tanto de la literatura árabe como de la occidental; en una entrevista a M. Villegas (1989-90: 423), cuando estaba preparando su siguiente novela, le comenta:

- ¡Ojalá fuera una novela como Don Quijote de la Mancha! Me parece genial, de lo más grande que ha producido la humanidad. Y artísticamente tiene ya toda la estética y todas las características de la novela actual, contemporánea.

El doctor Mahmud ${ }^{\mathrm{c}}$ Ali Makki (n. 1929) -profesor en la Universidad de El Cairo y especialista en estudios andalusíes y españoles, que leyó su Tesis Doctoral en Madrid en los años 50 y enseñó en la Universidad Complutense- completa el conocimiento que tienen los lectores árabes sobre Don Quijote con una serie de ensayos sobre el personaje y su autor; entre ellos destaca el titulado "Cervantes" (Tirfantis, 1985), en el que describe muy bien la figura de Don Quijote y su dimensión simbólica, explicando las circunstancias históricas en las que surgió el arquetipo, la España de hace cuatro siglos (Viguera, 1995: 22; 1999: 5, 13). Y el poeta egipcio Ahmad Haykal (n. 1922) dedica a Don Quijote su poema "Historia del jinete y el caballo" (Hikayat al-faris wa-l-hisan), en Ecos de la flauta (Asda' al-nay, 1980) (Martínez Lillo, 1990: 310).

También el teatro egipcio reflejará el tema. Alfrid Faray (n. 1929) alude a Don Quijote y Sancho Panza en su comedia ${ }^{c}$ Ali Yanah al-Tabrizi y su sirviente Quffa ('Ali Yanah alTabrizi wa-tabic $u$-hu Quffa, 1968), haciendo de ambos y de la pareja cervantina dos seres complementarios, pues los soñadores Tabrizi y Don Quijote rechazan la realidad en pos de un mundo más humano, con justicia social y distribución de las riquezas (Badawi, 1987: 
179-180). Y recientemente Ibrahim Fathi ${ }^{c}$ Ašmawi le ha dedicado su drama Esperando a Don Quijote. Pieza teatral (Fi ntizar Dun Kišut. Masrahiya, 1998).

Según Martínez Lillo (1990: 310, 311), en la etapa posterior al 67 Don Quijote ha de dar respuesta a cuestiones más profundas, como "la propia existencia del hombre árabe contemporáneo", en un mundo que se derrumba a su alrededor. Es lo que hacen otros tres poetas egipcios -al-Fayturi, Abu Sinna y Suwaylim- al abordar esta figura "desde una perspectiva más universalista". En su estudio de 1990, Martínez Lillo analiza el tema en un poema de cada uno de ellos, que corresponden a tres tiempos: el ocaso, la muerte y el recuerdo de Don Quijote.

Su "ocaso" lo representa el "El nuevo Don Quijote" (Dun Kušut al-tani, 1970), de Recuérdame, África (Udkuri-ni ya Afriqiya, 1970), de Muhammad al-Fayturi (n. 1930), poeta egipcio de origen sudanés:

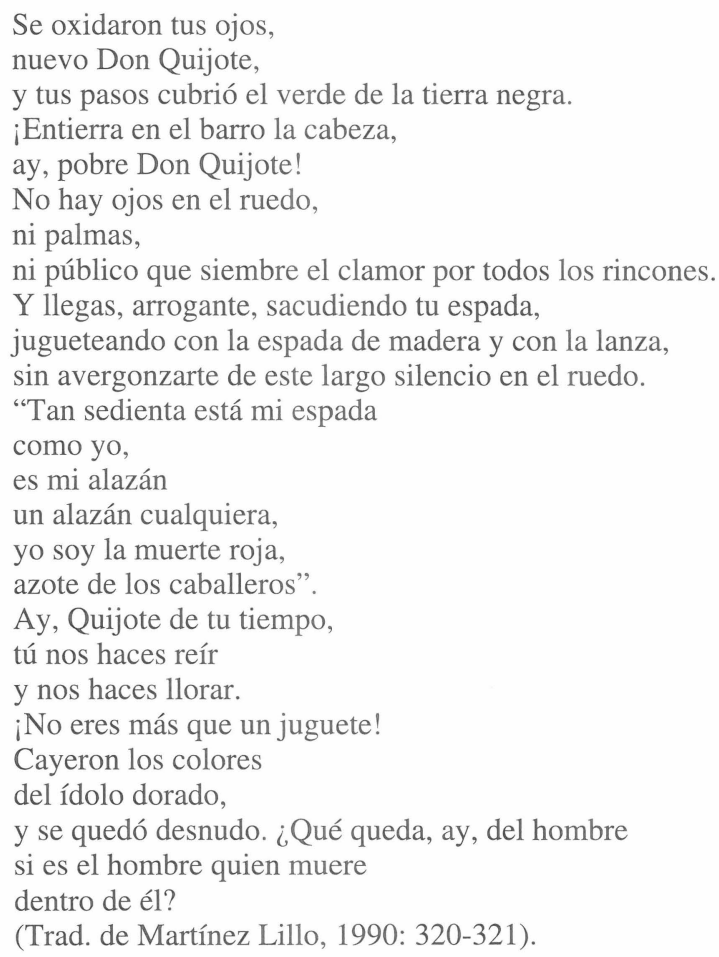

Este nuevo Quijote de al-Fayturi, que retorna en nuestra sociedad materialista, sufre la misma suerte que el original. En este desolador poema, el poeta lo equipara a un torero en declive, que ya no siente al público jaleando sus faenas en el ruedo. Está solo, como el literato árabe tras la derrota del 67, y se siente extraño; pero ninguno de ellos ceja en su combate por la justicia. El poeta seguirá siendo un incomprendido para su sociedad, que le considera un mero juguete y se burla de su idealismo, igual que hacía con el primitivo Don Quijote. Y se pregunta al-Fayturi: si matamos al Quijote que albergamos en nuestras entrañas, ¿qué va a quedar de nosotros? ¿qué va a quedar del Hombre? Por ello convierte al 
personaje en el símbolo de lo valores internos del ser humano (Martínez Lillo, 1990: 313), y del oriental en particular, en trance de perderse.

El estadio de su "muerte" lo representa el poema "Don Quijote en su lecho de muerte" (Dun Kišut ' alà firaš al-mawt), incluido en las Obras Poéticas (Al-a $a^{c}$ mal al-šíriya, 1985) del egipcio Muhammad Ibrahim Abu Sinna (n. 1937), en que el personaje habla en primera persona:

El miedo escribe su nombre sobre los muros de Córdoba.

La injusticia escribe su nombre sobre los muros de Córdoba.

$\mathrm{Y}$ en las calles de la ciudad castigada

se mueren sus profetas,

y los amantes se rinden al más largo bostezo,

mientras el sol la cubre al punto del crepúsculo

desde hace un siglo o más.

Heme aquí, en el lecho de muerte:

cargado de cadenas y de heridas,

en súplicas de jueces y testigos,

abandonado en medio de un estado de bárbaros.

Sobre mi viejo sable

atravesé los mares de este mundo caduco,

anhelando que el verde de las plantas

fluyera por el tiempo.

Salí en busca del hombre,

y lo encontré en los ojos de la mujer más bella:

Dulcinea, la lejana.

Soñé con islas, sueltas,

recorriendo los mares:

Con un mundo de nobles caballeros.

Con seguridad y justicia para todos.

Con el amor, del todo descubierto.

Soñé en poner a Córdoba

encima de las lomas de una verde estrella

volandera entre sombra y luz,

sobre cuyas mejillas las nubes escribieran

poemas encarnados y amarillos.

¡Hermosa Dulcinea!, soñé también

con un mundo en que los niños eran ángeles

y tenían el corazón de oro;

con el astro en el jardín de hojas plateadas,

de ramas en que los frutos permanecen

a lo largo del año.

Y soñé con palomas

que estaban tranquilamente en nuestros hombros,

y, si lo deseaban,

construían su nido en nuestras ropas.

Mas volví con heridas,

con escarnecedoras carcajadas;

con mi sable, en el polvo, destrozado

y lágrimas llenando los ojos del corcel.

Y Córdoba dejé:

Ciudad que la ventura no conoce.

Ciudad en donde manda la mentira. 
Y en tanto tú, lejana Dulcinea,

te pierdes cual la aurora por los bosques,

yo muero, tras el mar,

abandonado en medio de un estado de bárbaros.

Si te llega el anuncio de mi muerte,

que no se llenen de lágrimas tus ojos

ni dejes que en mi entierro

las mujeres den gritos de dolor.

Que me lleven jinetes

y que tras la litera suene el canto.

Porque no me arrepiento

si he gastado lo breve de mi edad

luchando por un mundo floreciente

y me han recompensado con heridas.

Veo ya los albores de la aurora

por los montes de Oriente

y veo ya las alas de la dicha

volando por el cielo de la mañana.

Para escribir su nombre

en los muros de Córdoba.

(Trad. de Martínez Montávez, en Martínez Lillo, 1990: 321-322).

En este poema de Abu Sinna, Don Quijote está en su lecho de muerte. Se siente un hombre incomprendido, pero, aún así, no se arrepiente de haber gastado su vida en luchar por un mundo justo y veraz en contra de la barbarie que el poeta ha visto apoderarse de su mundo, simbolizado por una Córdoba caída e injusta. En este poema el poeta concede gran importancia al amor, como móvil de su lucha, erigiéndolo en valor supremo para todo ser humano, representado en el amor de Don Quijote hacia Dulcinea, convertida aquí en símbolo de la patria y la ciudad amada. Como bien señala Martínez Lillo (1990: 315-316), Don Quijote/Abu Sinna, aparentemente fracasado por el abandono de su amada y las heridas recibidas, siente que su mensaje ha prendido y que brilla una luz de esperanza para su Córdoba andalusí y su Oriente árabe contemporáneo.

Y el estadio del "recuerdo" lo representa el poema "Ante la estatua de Don Quijote" (Amama timtal Dun Kišut), de El viaje y las condecoraciones (Al-safar wa-l-awsima, 1985) del egipcio Ahmad Suwaylim (n. 1942). En sus versos, el poeta desgrana sus reflexiones ante una estatua de Don Quijote, probablemente la que se halla en la Plaza de España de Madrid, y dice, dirigiéndose a ella:

Te doy los buenos días... pero tú no respondes

porque tu espada ígnea es la que se ocupa;

es como si atinara;

entrenada en las luchas y en las guerras,

nunca yerra el camino.

Te doy los buenos días

mas tú, ahora, quisieras que cayera

bajo tu pobre caballo...

Gritas en la cara de quienes se burlan...

¡Ni fracasaste tú... ni te rendirás!

Un rato me quedé a la sombra de un árbol.

Tú empuñabas la espada 
y agarrabas el cuello del caballo.

Yo veía en tus ojos la angustia del jinete

que vuelve sin espadas ni botín.

Parecía que tu pobre corcel

iba casi desmayado

de tanta hambre, de acechar el destino,

y que aquel escudero que te seguía

estaba, ahora, preso en alcázares falsos,

y que tu espada mágica

no era ya victoriosa ni eficaz.

Parecía que con tan sólo dar un paso hacia adelante

caerías en el abismo del naufragio.

Pero yo percibí, antes de separarme,

que estás hecho de acero y de estaño,

y que ellos,

al dejarte así, tirado en el descampado,

querían que siguiéramos tu marcha, que diéramos tu grito

en la cara de quienes vendieron nuestro destino,

y pararon los pasos... y nos cubrieron de heridas,

para que cuando, amigos, amaneciera,

aun sin respuesta tuya,

supiéramos que estamos rodeados de vergüenza.

¡Qué gozo nos traerían mil y una mañanas

aunque el soñado sol de salvación no despuntara!

Ahora, amigo mío,

sabemos por qué no respondiste a los ojos irónicos,

cómo tu espada ígnea

le atraviesa el pecho a ese espacio

sin desmayar, sin aburrirse..

Gritando a los que pasan.

¡Que se burlen, lo mismo que yo, y que abran bien los ojos!

No sonreirá el mañana nuevamente,

y todo aquel que pase por aquí

sentirá vergüenza (Trad. de Martínez Lillo, 1990: 322-323).

Aunque a primera vista le parece a Suwaylin que el personaje sugiere sólo derrota, en realidad lo siente como una negación de cualquier fracaso o rendición, pues encarna un grito eterno contra aquellos que se burlan de lo que él representa y proclama la vergüenza que han de sentir quienes lo han dejado tirado y herido en el descampado, en la patria árabe derrotada y escarnecida. Esa estatua de Don Quijote, hecha de acero y estaño, se convierte así en símbolo de resistencia y triunfo, en acicate para toda una sociedad árabe avergonzada y vencida, en estímulo ante cualquier fracaso, ante la fragilidad del poeta árabe, a lo largo de la lucha de su pueblo -hoy simbolizado en el pueblo palestino- contra aquellos que "vendieron su destino".

Según Viguera (1999: 17), puede decirse que novelistas y poetas han encarnado en Don Quijote una parte muy importante del discurso vital contemporáneo de los hombres y mujeres árabes, especialmente en la década de los 70 , donde el símbolo quijotesco resultó muy adecuado para que el literato árabe recurriera a él como expresión de la contradicción 
entre realismo e idealismo, y donde Don Quijote ha sido, en árabe también, arquetipo del idealismo, derrotado por su lejanía de la realidad, como cuando dice Nizar Qabbani que terminó la guerra de Junio pero siguen los "Don Quijote" con sus ilusiones, o cuando el iraquí Aršad Tawfiq invita a recuperar el quijotismo bueno y rechazar el malo. Parece claro que el literato árabe se "identifica" con el idealismo de Don Quijote y se hermana con él. La clave está en una secuencia de identificaciones magníficas: al-Andalus resulta ser asimilada con España, Don Quijote por tanto asimilado con los andalusíes, y al-Andalus es sentida con igual emoción que Palestina...

Para la mayoría de estos escritores árabes, Don Quijote, en apariencia derrotado, simboliza la esperanza, la lucha, la resistencia y la anhelada victoria final, por encima del tiempo y del espacio. Es un héroe con personalidad que sabe estar por encima de la incomprensión y del escarnio. Es un luchador que no ceja en defender sus ideales. Es un personaje que representa la esencia misma del ser humano en una sociedad materialista y corrupta. Como bien concluye Martínez Lillo (1990: 320) en su estudio, Don Quijote "se dibuja como alternativa" a la pasividad: es "el símbolo del hombre árabe actual, del luchador infatigable que confía en la victoria última, del soñador activo que realiza sus batallas en medio de donde impera la injusticia, la opresión, la vergüenza. Por ello, ¿no será el hombre árabe de hoy en día un Don Quijote en potencia?".

\section{REFERENCIAS BIBLIOGRÁFICAS}

BADAWI, M. M., Modern Arabic Drama in Egypt, Cambridge University Press, Cambridge, 1987.

CHUKRI, Muhamma, "Chukri: Yo me he casado con mis lecturas, mis escritos y misamigos" (www.mundoarabe.org/entrevistaMohamed_chukrimphp), 2000 (entrevista)

DARWISH, Mahmud, Memoria para el olvido, Trad. de M. C. Feria, Ediciones del Oriente y del Mediterráneo, Guadarrama, 1997.

Don Quijote/Dun Kijutih, Instituto Cervantes. Varios autores, AECI-Embajada de España, Ammán, 1999.

Literatura Iraquí Contemporánea. Prólogo y nota preliminar de Martínez Montávez. Varios traductores, Instituto Hispano-Árabe de Cultura, Madrid, 1977.

MARTÍNEZ LILLO, Rosa-Isabel. “Aproximación a la figura de Don Quijote en la poesía egipcia contemporánea". La traducción y la crítica literaria. Actas de las Jornadas de Hispanismo Árabe, AECI-ICMA, Madrid, 1990, pp. 307-323.

MARTÍNEZ MARTÍN, Leonor, Antología de poesía árabe contemporánea, Espasa-Calpe, Madrid, 1972.

MARTÍNEZ MONTÁVEZ, Pedro, Nizar Kabbani. Respuesta a los actores, Casa HispanoÁrabe, Madrid, 1969.

MARTÍNEZ MONTÁVEZ, Pedro, Nizar Kabbani. Poemas políticos. Visor, Madrid, 1975.

MARTÍNEZ MONTÁVEZ, Pedro, "El tema español en la poesía de Nizar Kabbani”. Exploraciones en Literatura Neoárabe. Instituto Hispano-Árabe de Cultura, Madrid, 1977, pp. 11-32. 
MARTÍNEZ MONTÁVEZ, Pedro, Al-Andalus, España, en la literatura árabe contemporánea. Editorial Arguval, Málaga, 1992.

RAMOS, Ana, "O escritor sírio Hani al-Rahib", Internet. <www.hottopos.com/collatio/o_escritor_sirio_hani-alrahib.htm) >, 1978.

RAMOS, Ana, "Don Quijote" [de Hani al-Rahib], en Don Quijote, 1999, pp. 21-27.

SURUR, Naguib, Hacer imprescindible lo que es necesario, Trad. de Santiago Alba y Javier Barreda, CantArabia, Madrid, 1993.

VIGUERA MOLINS, Mª Jesús, "Don Quijote en andadura egipcia (Cuatro ensayos egipcios contemporáneos sobre Don Quijote)", Almenara, no 7-8 (1975) 143177.

VIGUERA MOLINS, Ma Jesús, "Más sobre Don Quijote en la literatura árabe contemporánea", Revista del Instituto Egipcio de Estudios Islámicos, XXVII (1995) 9-22.

VIGUERA MOLINS, Ma Jesús, "El arabismo de Don Quijote”, Don Quijote, 1999, pp. 119.

VIGUERA MOLINS, Ma Jesús, "Recordando en Iraq a Don Quijote", Revista del Instituto Egipcio de Estudios Islámicos, XXXV (2003) 39-50. 